\title{
PHENOTYPIC ADAPTABILITY OF COTTON GENOTYPES TO THE BRAZILIAN CERRADO FOR YIELD AND FIBER QUALITY
}

\author{
ADAPTABILIDADE FENOTÍPICA DE GENÓTIPOS DE ALGODÃO AO CERRADO \\ BRASILEIRO PARA PRODUTIVIDADE E QUALIDADE DE FIBRAS.
}

\section{Mayara Fávero COTRIM'; Francisco José Correa FARIAS²; Luiz Paulo de CARVALHO²; Larissa Pereira Ribeiro TEODORO' ${ }^{\text {; }}$ Carlos Antonio da SILVA JUNIOR ${ }^{3}$; Paulo Eduardo TEODORO'}

1. Universidade Federal de Mato Grosso do Sul - UFMS, Chapadão do Sul, MS, Brasil; 2. Embrapa Algodão, Campina Grande, PB, Brasil; 3. Universidade do Estado do Mato Grosso - UNEMAT, Sinop, MT, Brasil. eduteodoro@hotmail.com

\begin{abstract}
Studies on the adaptability and stability are fundamental for plant breeding as they are an alternative to reduce the effects of genotypes $\mathrm{x}$ environments interaction (GxE). Moreover, they help identify cultivars with predictable behavior, which are responsive to environmental improvements, subsidizing cultivar recommendation. This study aimed to evaluate the genotypes $\mathrm{x}$ environments interaction in cotton genotypes grown in the Brazilian Cerrado and identify genotypes for favorable and unfavorable environments. During the 2013/2014 and 2014/2015 seasons, 19 competition trials were carried out with cotton in a randomized block design, with 12 treatments, and four replications. The traits cotton seed yield, fiber percentage, fiber length, and fiber strength were evaluated. Results revealed significant GxE interaction for all the fiber traits evaluated. Genotype BRS 369 RF revealed general adaptability and high predictability for the fiber traits evaluated.
\end{abstract}

KEYWORDS: Gossypium hirsutum. Adaptability and stability. Plant breeding.

\section{INTRODUCTION}

The production and release of cotton cultivars (Gossypium hirsutum) in Brazil rely on the producers' demands, who aim to meet the requirements of the textile industry (MORELLO et al. 2010, MORELLO et al. 2012, MORELLO et al. 2015). Before the cultivar recommendation, multiple trials are carried out to evaluate genotypes in different environments. The differential behavior of a genotype for a given trait in function of the environmental variation is defined as genotypes $\mathrm{x}$ environments interaction (GxE). Therefore, investigating this interaction is crucial for precisely recommending the best genotypes for a given region.

Breeders carry out several trials at the final stages of breeding programs. Embrapa Algodão has two experimental networks in two large regions: Cerrado and the semi-arid. The Cerrado biome occupies about $22 \%$ of the national territory and has peculiar climatic characteristics regarding rainfall regime, temperature, relative humidity of the air, and different types of soil. For these reasons, the GxE interaction in Cerrado environments should be investigated for the recommendation of cotton genotypes.

Several methodologies and methods have been made available for the investigation of the $\mathrm{GxE}$ interaction. The method proposed by Eberhart and Russel (1966) is based on the linear regression between the phenotypic value of a given trait in function of the environmental index. This index measures the quality of the environment, in which favorable environments have positive values, and unfavorable environments have negative values. The method also investigates the predictability of the genotype's behavior and thus enables the recommendation of genotypes for favorable and unfavorable environments and for environments with wide adaptability. The GxE interaction in agronomic traits such as cotton seed yield, fiber percentage, and fiber yield has been investigated in Brazil (SOUZA et al. 2006; SUINAGA; BASTOS; PACIFICI, 2006; FARIAS et al., 2016; TEODORO et al., 2018). These studies have identified genotypes that respond to environmental improvement, genotypes with higher rusticity, and genotypes with wide adaptability. The adequate recommendation for each environment increases the national production. However, studies investigating the GxE interaction in technological traits of cotton cultivars are still scarce in Brazil, and the only one available is that of Carvalho, Farias and Rodrigues (2015). The authors used the Eberhart and Russel (1966) method to identify genotypes with high predictability for all traits. 
Carvalho, Farias and Rodrigues (2015) also demonstrated that the GxE interaction in technological traits is complex, with a wide variation in genotype order throughout environments. Thus, this factor must be considered in genotypes recommendation to meet the demands of the textile industry. This study aimed to evaluate the GxE interaction in cotton genotypes grown in the Brazilian Cerrado and identify genotypes for favorable and unfavorable environments.

\section{MATERIAL AND METHODS}

Nineteen trials of cotton cultivars were carried out during the 2013/2014 and 2014/2015 seasons. The environments consisted of combining municipalities and seasons, according to the edaphoclimatic characteristics (Table 1) and graphical representation of the locations (Figure 1). The 12 standard cultivars were TMG $41 \mathrm{WS}$, TMG 43 WS, IMA CV 690, IMA 5675 B2RF, IMA 08 WS, NUOPAL, DP 555 BGRR, DELTA OPAL, BRS 286, BRS 335, BRS 368 RF, and BRS 369 RF. Cultivars were not the same in all years and locations, and thus the selection was based on the rainfall in the largest number of experiments, aiming to decrease the imbalance of the analyses of variance.

Table 1. Location and altitude (ALT), latitude (LAT), longitude (LONG), annual rainfall (RAIN), and average annual temperature (TEMP) in the 2013/2014 and 2014/2015 seasons.

\begin{tabular}{|c|c|c|c|c|c|c|c|c|}
\hline Location/State & Sigla $^{1}$ & Season & $\begin{array}{l}\text { Alt. } \\
(\mathrm{m})\end{array}$ & $\begin{array}{l}\text { Lat. } \\
(\mathrm{S})\end{array}$ & Long. (W) & $\begin{array}{l}\text { Rain } \\
(\mathrm{mm})\end{array}$ & $\begin{array}{l}\text { Temp. } \\
\left({ }^{\circ} \mathrm{C}\right)\end{array}$ & Climate $^{2}$ \\
\hline Trindade/MG & TRI & $2013 / 2014$ & 927 & $21^{\circ} 06^{\prime}$ & $44^{\circ} 10^{\prime}$ & 1467 & 23.2 & Aw \\
\hline $\begin{array}{l}\text { Santa Helena do } \\
\text { Goias/GO }\end{array}$ & $\begin{array}{l}\text { SHE1 } \\
\text { SHE2 }\end{array}$ & $\begin{array}{l}2013 / 2014 \\
2014 / 2015\end{array}$ & 562 & $17^{\circ} 48^{\prime}$ & $50^{\circ} 35^{\prime}$ & 1539 & 24.3 & Aw \\
\hline Pedra Preta/MT & $\begin{array}{l}\text { PPA1 } \\
\text { PPA2 } \\
\text { PVA1 }\end{array}$ & $\begin{array}{l}2013 / 2014 \\
2014 / 2015 \\
2013 / 2014\end{array}$ & 248 & $16^{\circ} 37^{\prime}$ & $54^{\circ} 28^{\prime}$ & 489 & 25.1 & Bsh \\
\hline $\begin{array}{l}\text { Primavera } \\
\text { leste/MT }\end{array}$ & $\begin{array}{l}\text { PVA2 } \\
\text { PVA3 } \\
\text { PVA4 }\end{array}$ & $\begin{array}{l}2013 / 2014 \\
2014 / 2015 \\
2014 / 2015\end{array}$ & 465 & $15^{\circ} 33^{\prime}$ & $54^{\circ} 17^{\prime}$ & 1784 & 22.0 & Aw \\
\hline Campo Verde/MT & $\begin{array}{l}\text { CV1 } \\
\text { CV2 }\end{array}$ & $\begin{array}{l}2013 / 2014 \\
2014 / 2015\end{array}$ & 736 & $15^{\circ} 32^{\prime}$ & $55^{\circ} 10^{\prime}$ & 1902 & 26.3 & Af \\
\hline Sinop/MT & SIN & $2013 / 2014$ & 345 & $11^{\circ} 51^{\prime}$ & $55^{\circ} 30^{\prime}$ & 1818 & 25.0 & Aw \\
\hline $\begin{array}{l}\text { Luiz Eduardo } \\
\text { Magalhães/BA }\end{array}$ & LEM & $2013 / 2014$ & 769 & $12^{\circ} 5^{\prime}$ & $45^{\circ} 47^{\prime}$ & 1511 & 24.2 & Aw \\
\hline São Desidério/BA & SDES & $2013 / 2014$ & 497 & $12^{\circ} 21^{\prime}$ & $44^{\circ} 58^{\prime}$ & 1289 & 24.7 & Aw \\
\hline Montividiu/GO & MON & $2013 / 2014$ & 821 & $17^{\circ} 26^{\prime}$ & $51^{\circ} 10^{\prime}$ & 1512 & 23.0 & Aw \\
\hline $\begin{array}{ll}\text { Magalhães } & \text { de } \\
\text { Almeida/MA } & \end{array}$ & MAG & $2013 / 2014$ & 36 & $03^{\circ} 23^{\prime}$ & $42^{\circ} 12^{\prime}$ & 1430 & 27.2 & Aw \\
\hline Teresina/PI & TER & $2013 / 2014$ & 72 & $05^{\circ} 05^{\prime}$ & $42^{\circ} 48^{\prime}$ & 1349 & 27.6 & Aw \\
\hline Chapadão do Sul/MS & CHA & $2014 / 2015$ & 810 & $18^{\circ} 47^{\prime}$ & $52^{\circ} 37^{\prime}$ & 1600 & 22.7 & Aw \\
\hline Sorriso/MT & SOR & $2014 / 2015$ & 365 & $12^{\circ} 32^{\prime}$ & $55^{\circ} 42^{\prime}$ & 1883 & 25.0 & Aw \\
\hline
\end{tabular}

${ }^{1}$ : locations abbreviations ${ }^{2}$ : Köppen classification.

The experiment was carried out in a randomized block design with 12 treatments and four replications. The experimental unit consisted of four $5-\mathrm{m}$ rows spaced at $0.90 \mathrm{~m}$ between rows, with a density of $9 \mathrm{~m}^{-1}$ plants. In each experimental unit, cotton seed yield $(\mathrm{Y})$ was evaluated in the two central rows, corrected to $13 \%$ moisture, and extrapolated to $\mathrm{kg} \mathrm{ha}^{-1}$ by the covariance method (VENCOVSKY; CRUZ, 1991).

Data were subject to joint analysis of variance, according to the model described in Equation 1:

$$
Y_{i j k}=\mu+B / E_{j k}+G_{i}+E_{j}+G_{i j}+e_{i j k}
$$

where:

$\mathrm{Y}_{\mathrm{ijk}}$ is the observation in the k-th block, evaluated in the $\mathrm{i}$-th genotype and $\mathrm{j}$-th environment; $\mu$ is the overall mean of the experiments; $\mathrm{B} / \mathrm{E}_{\mathrm{jk}}$ is the effect of block k within the environment $j$; $G_{i}$ is the effect of the $i$-th genotype considered as fixed; $E_{j}$ is the effect of the $\mathrm{j}$-th environment considered as random; $\mathrm{GE}_{\mathrm{ij}}$ is the random effect of the genotype $\mathrm{i}$ 
Phenotypic adaptability of cotton...

$\mathrm{x}$ environment $\mathrm{j}$ interaction; $\mathrm{e}_{\mathrm{ijk}}$ is the random error associated with the observation $\mathrm{Y}_{\mathrm{ijk}}$.

The means of the genotypes were compared by the Scott-Knott test at the 5\% probability. After verifying the significance of the GxE interaction, data were subject to the analyses of adaptability and stability, using the methodologies of Eberhart and Russell (1966), according to the following statistical model:

$$
Y_{i j}=\beta_{0 i}+\beta_{1 i} I_{j}+\psi_{i j}
$$

where: $Y_{i j}$ is the mean of genotype $i$ in environment $j ; \beta_{0 \mathrm{i}}$ is the linear coefficient of the $\mathrm{i}$-th genotype; $\beta_{1 \mathrm{i}}$ is the regression coefficient that measures the response of the i-th genotype to the variation of the environment $j ; \quad I_{j}$ is the environmental index

$$
\left(I_{j}=\frac{\sum_{j} Y_{j}}{g}-\frac{\sum_{i} \sum_{j} Y_{i j}}{g a}\right)
$$

$\psi_{\mathrm{ij}}$ are the random errors, in which each component can be decomposed as $\Psi_{\mathrm{ij}}=\delta_{\mathrm{ij}}+\bar{\varepsilon}_{\mathrm{ij}}$, where $\delta_{\mathrm{ij}}$ is the deviations of regression and $\bar{\varepsilon}_{\mathrm{ij}}$ is the mean experimental error.

The analysis of adaptability and stability proposed by Eberhart and Russell (1966) is based on the linear regression analysis, in which genotypes with general or wide adaptability are those with $\bar{\beta}_{1 \mathrm{i}}$ $=1$; genotypes with specific adaptability to favorable environments are those with $\widetilde{\beta}_{1 \mathrm{i}}>1$; and genotypes
COTRIM, M. F. et al.

with specific adaptability to unfavorable environments are those with $\hat{\beta}_{1 \mathrm{i}}<1$. The stability was evaluated by the deviations of regression $\left(\hat{\theta}^{2} \mathrm{di}\right)$ associated with the coefficient of determination $\left(\mathrm{R}^{2}\right)$; genotypes with $\hat{\theta}_{\mathrm{di}}^{2}=0$ and $\mathrm{R}^{2}$ above $70 \%$ were considered of to have predictable behavior, and genotypes with $\hat{\sigma}^{2}{ }_{\text {di }} \neq 0$ and $\mathrm{R}^{2}$ below $70 \%$ were considered to have unpredictable behavior. The hypotheses of interest are $\mathrm{H}_{0}: \beta_{1 \mathrm{i}}=1$ versus $\mathrm{H}_{1}$ : $\beta_{1 \mathrm{i}} \neq$ ; and $\mathrm{H}_{0}: \sigma_{\mathrm{di}}^{2}=0$ versus $\mathrm{H}_{1}: \sigma_{\mathrm{di}}^{2}>0$. The hypotheses were evaluated by the $\mathrm{t}$ and $\mathrm{F}$ tests at the $5 \%$ probability, respectively. Afterward, genotypes were classified into one of the six classes described in Table 2. All analyses were carried out in the Genes software (CRUZ, 2006).

\section{RESULTS AND DISCUSSION}

\section{Joint analysis of variance and classification of environments}

The F test (Table 3) indicated the similarity between the effects of genotypes for cotton seed yield (Y). However, the other traits had significance for the effects of genotypes $(p \leq 0.05)$, indicating genetic variability for traits FP, FL, and FR. The presence of the GxE interaction indicated the existence of variability of genotypes behavior throughout the environments for all the evaluated traits. Similar results were observed by other authors when studying the presence and absence of the GxE interaction in cotton in several locations in Brazil (SOUZA et al., 2006; SUINAGA; BASTOS; PACIFICI, 2006; SILVA FILHO et al., 2008; CARVALHO; FARIAS; RODRIGUES 2015; FARIAS et al. 2016).

Table 3. Summary of the analysis of variance for cotton seed yield (Y), fiber percentage (FP), fiber length (FL), and fiber strength (FS) of 12 early cotton genotypes carried out in 19 locations in the Brazilian

\begin{tabular}{|c|c|c|c|c|c|}
\hline \multirow{2}{*}{ Sources of Variation } & DF & $\mathrm{Y}$ & $\mathrm{FP}$ & FL & FR \\
\hline & \multicolumn{5}{|c|}{ Mean Square } \\
\hline Block/Environment & 54 & 582221.44 & 4.32 & 0.73 & 2.91 \\
\hline Genotypes (G) & 11 & $1310128.57^{\mathrm{ns}}$ & $136.68 *$ & $23.79 *$ & $79.78^{*}$ \\
\hline Environments (E) & 18 & $61511492.56^{*}$ & $104.32 *$ & $35.18 *$ & $88.02 *$ \\
\hline GxE & 198 & $874829.53^{*}$ & $7.84^{*}$ & $1.06^{*}$ & $3.76^{*}$ \\
\hline Residue & 627 & 333939.13 & 2.51 & 0.58 & $2.33 *$ \\
\hline CV $(\%)$ & & 13.88 & 3.77 & 2.55 & 5.04 \\
\hline
\end{tabular}
Cerrado, in the 2013/2014 and 2014/2015 seasons.

The significance of the GxE interaction may be due to predictable factors (soil management practices, pests and diseases, supplementary irrigation, base fertilization) and/or unpredictable 
factors (temperature, relative humidity of the air, and solar radiation during the crop cycle). The causes of this interaction are attributed to the adaptive factors and the scale of variables measurement. Therefore, the use of methods such as that of Eberhart and Russel (1966) are necessary to investigate the GxE interaction in these traits and identify genotypes with adaptation and behavior predictability for the environments of the Brazilian Cerrado.

Table 4 shows estimates of the environmental indices obtained by the Eberhart and Russel (1966) method for the 19 evaluated
COTRIM, M. F. et al.

environments. Positive values indicate that the environment had mean above the overall mean of all environments, and consequently, negative values indicate that the mean of the environment is below the overall mean of all environments. Environments PVA1 and SDES were the only ones with positive values, which characterizes them as favorable environments. Genotypes recommended for these environments should be able to respond to these favorable conditions, that is, they should be able to respond satisfactorily to high investments in agricultural practices (such as fertilization, irrigation, and pest, diseases, and weeds control).

Table 4. Environmental index (Ij) of cotton seed yield (Y), fiber percentage (FP), fiber length (FL), and fiber strength (FS) of 12 cotton genotypes in the 19 trials carried out in Cerrado in 2013/14 and 2014/15 seasons.

\begin{tabular}{|c|c|c|c|c|}
\hline \multirow{2}{*}{ Environment $^{1}$} & \multicolumn{4}{|l|}{$\mathrm{Ij}$} \\
\hline & $\mathrm{Y}$ & FP & FL & FS \\
\hline TRI & 1881.59 & 0.1951 & 0.6318 & -1.0498 \\
\hline SHE1 & 946.37 & -0.7849 & 0.6649 & 0.5927 \\
\hline PVA1 & 1162.16 & 0.5265 & 1.5330 & 1.0809 \\
\hline CV1 & -373.16 & -0.5335 & -0.2070 & -0.7629 \\
\hline SIN & -2747.02 & 2.8638 & -1.9776 & -2.6516 \\
\hline PVA2 & 101.84 & -0.1414 & 0.4633 & 0.5404 \\
\hline PPA1 & 609.04 & -1.3783 & 0.7585 & -1.4252 \\
\hline LEM & -257.66 & 0.5692 & 0.6347 & 1.0438 \\
\hline SDES & 1345.84 & 0.9109 & 0.6262 & 0.1307 \\
\hline MONT & -1348.88 & 0.3988 & -1.4586 & 0.2125 \\
\hline MAG & 264.83 & -2.0941 & 0.0860 & 1.9065 \\
\hline TER & 29.99 & 1.9051 & -1.0628 & 1.0036 \\
\hline PPA2 & 375.28 & -0.2328 & 0.1130 & -0.8877 \\
\hline CV2 & -440.47 & 1.2611 & -0.2088 & 0.1873 \\
\hline SHE2 & -934.86 & -2.1762 & -0.2080 & -0.9346 \\
\hline CHAP & 605.47 & 1.1151 & -0.0165 & -1.3631 \\
\hline PVA3 & 629.80 & -3.2372 & 0.4305 & 3.1186 \\
\hline SOR & -1863.59 & 0.3701 & -0.9459 & 0.3709 \\
\hline PVA4 & 13.37 & 0.4626 & 0.1433 & -1.1131 \\
\hline
\end{tabular}

${ }^{1}$ Abbreviations described in Table 1.

Conversely, environments CV1, SIN, and SHE2 were classified as unfavorable, except for the trait fiber percentage (FP) in the SIN environment. In these environments, genotypes with higher rusticity are desirable since a lower level of technology is employed. The classification of the other environments did not agree with each other for all traits, revealing higher complexity in the recommendation of cotton genotypes when considering both agronomic and technological traits.

Adaptability and stability of agronomic traits
Table 5 shows the mean cotton seed yield $\left(\tilde{\beta}_{0}\right)$ and the parameters of adaptability $\left(\tilde{\beta}_{1}\right)$ and stability $\left(\hat{\sigma}_{\mathrm{di}}^{2}\right.$ and $\left.\mathrm{R}^{2}\right)$, based on the Eberhart and Russell (1966) method. Considering these parameters, genotype IMA CV 690, besides the high yield, is also the most suitable for cultivation in favorable environments $\left(\tilde{\beta}_{1}>1\right)$ and has high behavior predictability $\left(\mathrm{R}^{2}>90 \%\right)$. This genotype can respond favorably to the environmental stimulus and should be used by producers who use high technology level. 
Table 5. Mean cotton seed yield $\left(\mathrm{kg} \mathrm{ha}^{-1}\right)$, coefficients of regression $\left(\tilde{\beta}_{1}\right)$, deviations of regression $\left(\hat{\sigma}_{\mathrm{di}}^{2}\right)$, and coefficient of determination $\left(\mathrm{R}^{2}\right)$ obtained by the Eberhart and Russel (1966) for12 cotton genotypes in 19 environments in the Brazilian Cerrado.

\begin{tabular}{lllll}
\hline Genotypes & Means $\left(\tilde{\beta}_{0}\right)$ & $\tilde{\beta}_{1}$ & $\theta^{2}{ }_{\text {di }}\left(\mathrm{x} 10^{6}\right)$ & $\mathrm{R}^{2}$ \\
\hline TMG 41 WS & $4225.87 \mathrm{a}$ & $0.99^{\mathrm{ns}}$ & $1.22^{*}$ & $1.22^{*}$ \\
TMG 43 WS & $4079.31 \mathrm{~b}$ & $0.84^{*}$ & $1.16^{*}$ & 82.62 \\
IMA CV 690 & $4473.31 \mathrm{a}$ & $1.17^{*}$ & $2.21^{*}$ & 90.33 \\
IMA 5675 B2RF & $3943.15 \mathrm{~b}$ & $0.74^{*}$ & $1.14^{*}$ & 80.19 \\
IMA 08 WS & $4078.12 \mathrm{~b}$ & $0.76^{*}$ & $0.53^{\mathrm{ns}}$ & 90.74 \\
NUOPAL & $4115.30 \mathrm{~b}$ & $0.99^{\mathrm{ns}}$ & $0.02^{\mathrm{ns}}$ & 95.08 \\
DP 555 BGRR & $4222.43 \mathrm{a}$ & $1.10^{\mathrm{ns}}$ & $0.68^{*}$ & 92.60 \\
DELTA OPAL & $4135.37 \mathrm{~b}$ & $1.18^{*}$ & $1.25^{*}$ & 87.05 \\
BRS 286 & $4188.34 \mathrm{a}$ & $1.01^{\mathrm{ns}}$ & $1.70^{*}$ & 85.88 \\
BRS 335 & $4053.95 \mathrm{~b}$ & $1.06^{\mathrm{ns}}$ & $0.61^{*}$ & 90.03 \\
BRS 368 RF & $4191.66 \mathrm{a}$ & $0.98^{\mathrm{ns}}$ & $0.45^{\mathrm{ns}}$ & 92.89 \\
BRS 369 RF & $4246.14 \mathrm{a}$ & $1.11^{\mathrm{ns}}$ & &
\end{tabular}

Among the genotypes, the most recommended for unfavorable environments were TMG 43 WS and IMA 08 WS. Although their mean was below the overall mean of all environments, they have behavior predictability $\left(\mathrm{R}^{2}>80 \%\right)$ and may be a good option for producers who grow cotton in the off-season, which is a period of high climatic instability in the Brazilian Cerrado.

According to the method applied, the ideal genotype should have high mean for the evaluated trait, $\tilde{\beta}_{1}=1$ (general adaptability), not-significant $\sigma_{\text {di }}^{2}$, and high $\mathrm{R}^{2}(>70 \%)$. Thus, genotypes BRS 369 RF and DP 555 BGRR were considered of general adaptability and are close to the ideal genotype described by Eberhart and Russel (1966). Therefore, they can be grown in any environment of the Brazilian Cerrado.
Regarding fiber percentage, only genotype IMA 5675 B2RF showed adaptability to favorable environments $\left(\tilde{\beta}_{\mathrm{Ii}}>1\right)$ and predictability $\left(\hat{\theta}_{\mathrm{di}}^{2}=0\right)$. However, its mean $\left(\hat{\sigma}_{\mathrm{di}}^{2}=0\right)$ was below the overall mean of all environments (Table 6). Stability indices equal or close to zero evidence predictability in the phenotypic expression. Similarly, genotype BRS 286 also showed adaptability to favorable environments $\left(\tilde{\beta}_{1-1}>1\right)$ and mean $\left(\tilde{\beta}_{\mathbb{E}}\right)$ below the overall mean; however, BRS 286 is associated with a high coefficient of determination $\left(\mathrm{R}^{2}>80 \%\right)$. Carvalho, Farias and Rodrigues (2015) found different results when evaluating the fiber percentage and observed low predictability in favorable environments for nine genotypes tested in the Brazilian Northeast region.

Table 6. Mean fiber percentage $(\%)$, coefficients of regression $\left(\hat{\beta}_{1}\right)$, deviations of regression $\left(\hat{\sigma}^{2}{ }_{\text {di }}\right)$, and coefficient of determination $\left(\mathrm{R}^{2}\right)$ obtained by the Eberhart and Russel (1966) method for 12 cotton genotypes in 19 environments in the Brazilian Cerrado.

\begin{tabular}{|c|c|c|c|c|}
\hline Genotypes & $\operatorname{Mean}\left(\bar{\beta}_{0}\right)$ & $\tilde{\beta}_{1}$ & $\hat{\sigma}_{\mathrm{di}}^{2}\left(\mathrm{x} 10^{6}\right)$ & $\mathrm{R}^{2}$ \\
\hline TMG $41 \mathrm{WS}$ & $40.33 \mathrm{~b}$ & $0.63 *$ & $1.05^{*}$ & 35.77 \\
\hline TMG 43 WS & $41.91 \mathrm{~b}$ & $0.89^{\text {ns }}$ & $0.54 *$ & 61.08 \\
\hline IMA CV 690 & $44.21 \mathrm{a}$ & $1.28 *$ & $6.13^{*}$ & 35.88 \\
\hline IMA 5675 B2RF & $41.42 \mathrm{~b}$ & $1.24 *$ & $0.29^{\mathrm{ns}}$ & 79.52 \\
\hline IMA $08 \mathrm{WS}$ & $42.90 \mathrm{a}$ & $0.82^{\mathrm{ns}}$ & $1.26^{*}$ & 45.31 \\
\hline NUOPAL & $39.89 \mathrm{~b}$ & $0.53 *$ & $0.52 *$ & 36.09 \\
\hline DP 555 BGRR & $44.12 \mathrm{a}$ & $1.22^{\mathrm{ns}}$ & $0.84^{*}$ & 70.15 \\
\hline DELTA OPAL & $40.84 \mathrm{~b}$ & $0.94^{\mathrm{ns}}$ & $1.76^{\mathrm{ns}}$ & 46.09 \\
\hline BRS 286 & $41.21 \mathrm{~b}$ & $1.33 *$ & $0.34^{*}$ & 80.87 \\
\hline BRS 335 & $41.77 \mathrm{~b}$ & $0.82^{\mathrm{ns}}$ & $0.77^{*}$ & 52.85 \\
\hline BRS $368 \mathrm{RF}$ & $42.05 \mathrm{a}$ & $1.11^{\mathrm{ns}}$ & $0.16^{\mathrm{ns}}$ & 78.23 \\
\hline BRS 369 RF & $42.30 \mathrm{a}$ & $1.13^{\text {ns }}$ & $-0.14^{\mathrm{ns}}$ & 86.01 \\
\hline Mean & 41.91 & & & \\
\hline
\end{tabular}


Genotypes NUOPAL and TMG 41 WS are considered as adapted to unfavorable environments and as having low behavior predictability. However, the reliable recommendation of these genotypes is not possible due to low values of the coefficients of determination of both genotypes $\left(\mathrm{R}^{2}<40 \%\right)$, besides the unsatisfactory mean (below the overall mean). These results confirm the complexity of the GxE interaction in relation to fiber traits, which reinforces the need for evaluating genotypes in appropriate environments trials for which the materials are being developed.

Genotype BRS 369 RF was the ideal genotype, surpassing the others due to the high mean $\left(\tilde{\beta}_{0}\right)$, adaptability to several environments $\left(\tilde{\beta}_{1}=1\right)$, and high predictability $\left(\hat{\sigma}_{\mathrm{di}}^{2}=0\right.$ and $\mathrm{R}^{2}>86 \%$ ). Identifying the genotypes with better representativeness and performance is crucial, especially at the final stages of breeding programs.

\section{Adaptability and stability of technological traits}

Genotype BRS 286 responded to favorable environments regarding fiber length. However, this genotype showed low predictability $\left(\hat{\sigma}_{\mathrm{di}}^{2}<0\right)$, as indicated in Table 7. Since this genotype did not respond to environmental improvement, more evaluations with genotypes at a different location are recommended.

Table 7. Mean fiber length (mm), coefficients of regression $\left(\tilde{\beta}_{1}\right)$, deviations of regression $\left(\hat{\sigma}^{2}{ }_{\mathrm{di}}\right)$, and coefficient of determination $\left(\mathrm{R}^{2}\right)$, obtained by the Eberhart and Russel (1966) method for 12 cotton genotypes in 19 environments of the Brazilian Cerrado.

\begin{tabular}{lllll}
\hline Genotypes & Mean $\left(\tilde{\beta}_{0}\right)$ & $\tilde{\beta}_{1}$ & $\tilde{\sigma}_{\mathrm{di}}^{2}\left(\mathrm{x} 10^{6}\right)$ & $\mathrm{R}^{2}$ \\
\hline TMG 41 WS & $29.13 \mathrm{~b}$ & $0.69^{*}$ & $0.06^{\mathrm{ns}}$ & 63.75 \\
TMG 43 WS & $29.29 \mathrm{~b}$ & $0.92^{\text {ns }}$ & $0.00^{\text {ns }}$ & 81.88 \\
IMA CV 690 & $29.36 \mathrm{~b}$ & $0.90^{\text {ns }}$ & $0.09^{\text {ns }}$ & 73.07 \\
IMA 5675 B2RF & $29.39 \mathrm{~b}$ & $1.05^{\text {ns }}$ & $0.13^{*}$ & 75.66 \\
IMA 08 WS & $31.04 \mathrm{a}$ & $0.96^{\text {ns }}$ & $0.35^{*}$ & 59.19 \\
NUOPAL & $30.19 \mathrm{a}$ & $0.94^{\text {ns }}$ & $0.01^{\text {ns }}$ & 80.99 \\
DP 555 BGRR & $29.50 \mathrm{~b}$ & $1.12^{\text {ns }}$ & $-0.03^{\text {ns }}$ & 90.12 \\
DELTA OPAL & $29.76 \mathrm{~b}$ & $0.87^{\text {ns }}$ & $0.13^{*}$ & 68.39 \\
BRS 286 & $29.84 \mathrm{~b}$ & $1.35^{*}$ & $0.34^{*}$ & 74.54 \\
BRS 335 & $30.46 \mathrm{a}$ & $0.90^{\text {ns }}$ & $0.07^{\text {ns }}$ & 84.62 \\
BRS 368 RF & $29.51 \mathrm{~b}$ & $1.07^{\text {ns }}$ & $-0.02^{\text {ns }}$ & 89.51 \\
BRS 369 RF & $30.09 \mathrm{a}$ & $1.16^{\text {ns }}$ & $-0.02^{\text {ns }}$ & \\
\hline Mean & 29.79 & & &
\end{tabular}

*. ns. significant and non-significant, respectively, by the $\mathrm{F}$ test at $5 \%$ probability.

When evaluating the unfavorable environments, genotype TMG 41WS showed high stability at the locations CV1, SIN, and SHE2, as previously verified in the environmental index. However, since the coefficient of determination is below $70 \%$, this information is not precise. Several studies on different levels of association between adaptability and stability methodologies recommend the use of more than one method for the safe prediction of genotype performance (SILVA; DUARTE, 2006; ROOSTAEI; MOHAMMADI; AMRI, 2014).

Means $\left(\tilde{\beta}_{0}\right)$ above the overall mean for fiber length were observed for genotypes BRS 335, NUOPAL, and BRS 369RF. The wide adaptation $\left(\widehat{\beta}_{1}=1\right)$ to the change of environment and the classification as ideal genotype was confirmed by their $\mathrm{R}^{2}>70 \%$. Among these genotypes, BRS 369 $\mathrm{RF}$ stood out for having this same behavior for more than one trait.
For the trait fiber strength (Table 8), genotypes IMA 08 WS and BRS 286 showed high predictability $\left(\hat{\sigma}_{\mathrm{d}}^{2}=0\right)$ mainly in favorable environments $\left(\tilde{\beta}_{1}>1\right)$, as observed at the locations SDES and PVA1, both with positive environmental index. Moreover, the results for fiber strength were similar to those obtained for fiber length, in which BRS 286 genotype is considered to be the ideal genotype, confirming high reproducibility in environments with high technology, such as favorable environments.

Similar to what occurred to FL and Y, results did not reveal any precise recommendation of genotypes for unfavorable environments $\left(\widetilde{\beta}_{1}<1\right)$. Although genotypes NUOPAL and BRS 368 RF had $\AA_{\mathrm{di}}^{2}=0$, their coefficients of determination were below the ideal $\left(\mathrm{R}^{2}<70 \%\right)$, demonstrating inconsistencies. 
Table 8. Mean of fiber strength (UHM), coefficients of regression $\left(\hat{\beta}_{1}\right)$, deviations of regression $\left(\hat{\sigma}^{2}{ }_{\mathrm{di}}\right)$, and coefficient of determination $\left(\mathrm{R}^{2}\right)$ obtained by the Eberhart and Russel (1966) method for 12 cotton genotypes in 19 Brazilian Cerrado environments.

\begin{tabular}{lllll}
\hline Genotypes & Mean $\left(\tilde{\beta}_{\varpi}\right)$ & $\tilde{\beta}_{1}$ & $\hat{\theta}_{\text {di }}^{2}\left(\mathrm{x} 10^{6}\right)$ & $\mathrm{R}^{2}$ \\
\hline TMG 41 WS & $32.07 \mathrm{a}$ & $1.14^{\mathrm{ns}}$ & $0.51^{*}$ & 69.80 \\
TMG 43 WS & $30.93 \mathrm{a}$ & $1.24^{\mathrm{ns}}$ & $-0.15^{\mathrm{ns}}$ & 87.68 \\
IMA CV 690 & $30.97 \mathrm{a}$ & $0.57^{*}$ & $0.90^{*}$ & 29.95 \\
IMA 5675 B2RF & $28.69 \mathrm{~b}$ & $1.26^{*}$ & $0.69^{*}$ & 70.71 \\
IMA 08 WS & $29.99 \mathrm{a}$ & $1.30^{*}$ & $0.02^{\mathrm{ns}}$ & 84.45 \\
NUOPAL & $30.84 \mathrm{a}$ & $0.72^{*}$ & $-0.05^{\mathrm{ns}}$ & 65.82 \\
DP 555 BGRR & $28.91 \mathrm{~b}$ & $0.81^{\mathrm{ns}}$ & $0.35^{\text {ns }}$ & 57.87 \\
DELTA OPAL & $31.61 \mathrm{a}$ & $0.98^{\mathrm{ns}}$ & $-0.22^{\mathrm{ns}}$ & 83.94 \\
BRS 286 & $30.45 \mathrm{a}$ & $1.26^{*}$ & $0.12^{\text {ns }}$ & 81.33 \\
BRS 335 & $29.87 \mathrm{~b}$ & $1.02^{\mathrm{ns}}$ & $-0.11^{\mathrm{ns}}$ & 81.23 \\
BRS 368 RF & $29.50 \mathrm{~b}$ & $0.62^{*}$ & $-0.08^{\mathrm{ns}}$ & 60.34 \\
BRS 369 RF & $30.01 \mathrm{~b}$ & $1.02^{\mathrm{ns}}$ & $0.49^{*}$ & 65.44 \\
\hline
\end{tabular}

Mean 30.32

* ${ }^{\text {ns: }}$ significant and non-significant, respectively, by the $\mathrm{F}$ test at the $5 \%$ of probability.

Only genotype TMG 43 WS showed general adaptability. Thus, this genotype is the only one with wide adaptability for fiber strength, that is, it can maintain similar behavior if grown in environments similar to those reported in this study. Results revealed significant changes in genotypes behavior at different locations, reinforcing the need for developing more genotypes adapted to different environments. However, these results indicate that, since several cultivars are released continuously, they need to be evaluated in more locations and years.

\section{CONCLUSIONS}

Genotype BRS $369 \mathrm{RF}$ is considered as an
ideal genotype regarding agronomic and technological fiber traits (except for fiber strength), revealing the best performance in multiple Brazilian Cerrado environments.

Genotype BRS 286 is predictable and responsive to environmental improvements for fiber technological traits and fiber percentage, being the most suitable for cultivation in favorable environments.

In unfavorable environment conditions, no genotype showed satisfactory performance considering more than one trait. However, genotypes TMG 43 WS and IMA 08 WS revealed stability for cotton seed yield and could be a good option for cotton producers who use low technology in the Brazilian Cerrado.

RESUMO: Estudos sobre a adaptabilidade e estabilidade são fundamentais para o melhoramento de plantas, pois são considerados uma alternativa para reduzir os efeitos da interação genótipos $\mathrm{x}$ ambientes (GxE) e identificar cultivares com comportamento previsível e responsivo a melhorias ambientais, subsidiando a recomendação de cultivares. Este trabalho teve como objetivo investigar a interação genótipos $\mathrm{x}$ ambientes em genótipos de algodoeiro cultivados no Cerrado brasileiro e identificar genótipos para ambientes favoráveis e desfavoráveis. Durante as safras 2013/2014 e 2014/2015, foram realizados 19 ensaios de competição com algodão em delineamento de blocos ao acaso, com 12 tratamentos e quatro repetições. As características produtividade de sementes de algodão, porcentagem de fibras, comprimento de fibra e resistência das fibras foram avaliadas. Os resultados revelaram interação significativa da GxE para todas as características da fibra avaliada. O genótipo BRS 369 RF revelou adaptabilidade geral e alta previsibilidade para as características da fibra avaliada.

PALAVRAS-CHAVE: Gossypium hirsutum. Adaptabilidade e estabilidade. Melhoramento de plantas. 


\section{REFERENCES}

CARVALHO, L. P.; FARIAS, F. J. C.; RODRIGUES, J. I. S. Selection for increased fiber length in cotton progenies from Acala and non-Acala types. Crop Science, v. 55, p. 985-991, 2015.

https://doi.org/10.2135/cropsci2014.08.0547

EBERHART, S. A.; RUSSELL, W. A. Stability parameters for comparing varieties. Crop Science, v. 6, p. 3640, 1966. https://doi.org/10.2135/cropsci1966.0011183X000600010011x

FARIAS, F. J. C.; CARVALHO, L. P.; SILVA FILHO, J. L.; TEODORO, P. E. Correlations and path analysis among agronomic and technological traits of upland cotton. Genetics and Molecular Research, v.15, gmr.15038239, 2016b. https://doi.org/10.4238/gmr.15038239

MORELLO, C. L.; SUASSUNA, N. D.; FARIAS, F. J. C.; LAMAS, F. M.; PEDROSA, M. B.; RIBEIRO, J. L.; GODINHO, V. P. C.; FREIRE, E. C. BRS 293: A midseason highyielding upland cotton cultivar for Brazilian savanna. Crop Breeding and Applied Biotechnology, v. 10, p. 180-182, 2010. https://doi.org/10.12702/1984-7033.v10n02a13

MORELLO, C. L.; PEDROSA, M.B.; SUASSUNA, N. D.; LAMAS, F. M.; CHITARRA, L. G.; SILVA, J. L.; ANDRADE, F. P.; BARROSO, P. A. V.; RIBEIRO, J. L.; GODINHO, V. P. C.; LANZA, M. A. BRS 336: a high-quality fiber upland cotton cultivar for Brazilian savanna and semi-arid conditions. Crop Breeding and Applied Biotechnology, v. 12, p. 92-95, 2012. https://doi.org/10.1590/S1984-70332012000100012

MORELlO, C. L.; SUASSUNA, N. D.; BARROSO, P. A. V.; SILVA FILHO, J. L.; FERREIRA, A. C. B.; LAMAS, F. M.; PEDROSA, M. B.; CHITARRA, L. G.; RIBEIRO, J. L.; GODINHO, V. P. C.; LANZA, M. A. BRS 369RF and BRS 370RF: Glyphosate tolerant, high-yielding upland cotton cultivars for central Brazilian savanna. Crop Breeding and Applied Biotechnology, v. 15, p. 290-294, 2015. https://doi.org/10.1590/1984$70332015 \mathrm{v} 15 \mathrm{n} 4 \mathrm{c} 49$

ROOSTAEI, M.; MOHAMMADI, R.; AMRI, A. Correlação de postos entre diferentes modelos estatísticos no ranking de genótipos de trigo de inverno. The Crop Journal, v. 2, p. 154-163, 2014.

https://doi.org/10.1016/j.cj.2014.02.002

SILVA, W. C. J.; DUARTE, J. B. Métodos estatísticos para o estudo de adaptabilidade e estabilidade fenotípica em soja. Pesquisa Agropecuária Brasileira, v. 41, p. 23-30, 2006. https://doi.org/10.1590/S0100204X2006000100004

SILVA FILHO, J. L.; MORELLO, C. L.; FARIAS, F. J. C.; LAMAS, F. M.; PEDROSA, M. E.; RIBEIRO, J. L. 2008. Comparação de métodos para avaliar a adaptabilidade e estabilidade produtiva em algodoeiro. Pesquisa Agropecuária Brasileira, v. 43, p. 349-355. https://doi.org/10.1590/S0100-204X2008000300009

SOUZA, A. A.; FREIRE, E. C.; BRUNO, R. L. A.; CARVALHO, L. P.; SILVA FILHO, J. L.; PEREIRA, W. E. Estabilidade e adaptabilidade do algodoeiro herbáceo no cerrado do mato grosso e mato grosso do sul. Pesquisa agropecuária brasileira, Brasília, v. 41, n. 7, p. 1125-1131,2006. https://doi.org/10.1590/S0100204X2006000700008

SUINAGA, F. A.; BASTOS, C. S.; PACIFICI, L. E. R. Phenotypic adaptability and stability of cotton cultivars in Mato Grosso State, Brazil. Pesquisa Agropecuária Tropical, 36, p.145-150, 2006.

TEODORO, P. E., F. J. CORREIA FARIAS, L. PAULO DE CARVALHO, M. NASCIMENTO, L. DE AZEVEDO PEIXOTO, C. D. CRUZ, AND L. L. BHERING. Identification of Optimal Environments for Cotton Cultivars in the Brazilian Cerrado. Agronomy Journal, 110, p. 1226-1232, 2018. doi:10.2134/agronj2017.12.075

VENCOVSKY, R.; CRUZ, C. D. Comparação de métodos de correção do rendimento de parcelas com estandes variados: I. Dados simulados. Pesquisa Agropecuária Brasileira, v. 26, p. 647-657, 1991. 